\title{
As primeiras fábricas de papel na cidade do Rio de Janeiro no século XIX
}

\author{
The first paper factories in the city of Rio de \\ Janeiro in the 19th century \\ Las primeras fábricas de papel en la ciudad de \\ Río de Janeiro en el siglo XIX
}

Thais Helena de Almeida Fundação Biblioteca Nacional E-mail: thais.slaibi@bn.gov.br ORCID: 0000-0001-5366-8395

\author{
Ozana Hannesch \\ Museu de Astronomia e Ciências Afins \\ E-mail: ozana@mast.br \\ ORCID: 0000-0001-6630-2843
}

\section{RESUMO:}

Este artigo busca um entendimento cronológico do desenvolvimento da indústria de papel e de sua matéria-prima na cidade do Rio de Janeiro, no século XIX. Por meio de fontes primárias de pesquisa e de levantamentos em jornais e livros publicados no período, foi possível identificar alguns empreendedores e confirmar a participação do Governo Imperial no impulsionamento desta indústria. Contudo, essas fábricas foram impactadas por inúmeras dificuldades de um país em transformação e em fase de consolidação política e econômica, refletindo no seu desempenho, produção e investimento na pesquisa e uso de fibras nativas brasileiras, na tentativa de substituição das fibras de trapo importadas da Europa. Os avanços foram poucos no período, no entanto, encorajaram outros investimentos papeleiros no Brasil.

Palavras-chave: Fábricas de papel. Papel brasileiro. Fibras nativas.

ALMEIDA, Thais Helena de; HANNESCH, Ozana. As primeiras fábricas de papel na cidade do Rio de Janeiro no século XIX.

PÓS:Revista do Programa de Pós-graduação em Artes da EBA/UFMG. v. 11, n. 22, mai-ago. 2021 Disponível em < $\underline{\text { https://doi.org/10.35699/2237-5864.2021.25766 }}>$ 


\section{ABSTRACT:}

This paper is seeking a chronological understanding the paper industry development and its raw materials in the city of Rio de Janeiro, in 19th century. Through primary sources of research and surveys in newspapers and books published in the period, was possible to identify entrepreneurs and confirm that the Imperial Government participated in boosting it. However, these factories were impacted by countless difficulties of a country in transformation and in phase of political and economic consolidation, reflecting in its performance, production and investment in the research and use native Brazilian fibers, to replace the rag fibers imported from Europe. There were little advances made in this period, however, it encouraged further investments in paper making in Brazil.

Keywords: Paper factory. Brazilian paper. Native fibers.

\section{RESUMEN:}

Este artículo busca comprensión cronológica del desarrollo de la industria del papel y su materia prima en la ciudad de Río de Janeiro en el siglo XIX. Mediante fuentes primarias y encuestas en periódicos y libros publicados en aquel período fue posible identificar empresarios y confirmar la participación del Gobierno Imperial hacia la incrementación de esta industria. Sin embargo, esas fábricas han sido afectadas por numerosas dificultades de un país en una fase de consolidación política y económica. Eso reflejó en el rendimiento, producción e inversión de las fábricas para la investigación y uso de fibras nativas brasileñas, en el intento de reemplazar las fibras de trapo importadas de Europa. Sin embargo, se hicieron pocos progresos, pero encorajaran otros fabricantes de papel hacer inversiones en el Brasil.

Palabras clave: Fábricas de papel. Papel brasileño. Fibras nativas.

Artigo recebido em: 10/10/2021

Artigo aprovado em: 20/01/2021

ALMEIDA, Thais Helena de; HANNESCH, Ozana. As primeiras fábricas de papel na cidade do Rio de Janeiro no século XIX.

PÓS:Revista do Programa de Pós-graduação em Artes da EBA/UFMG. v. 11, n. 22, mai-ago. 2021 Disponível em < $\underline{\text { https://doi.org/10.35699/2237-5864.2021.25766 }>}$ 


\section{Da proibição das indústrias ao incentivo a suas instalações}

No Alvará de 5 de janeiro de 1785, D. Maria I, rainha de Portugal, proibia o estabelecimento de fábricas e manufaturas no Brasil, sob o argumento de que com o seu desenvolvimento os colonos deixariam de cultivar e explorar as riquezas da terra e de fazer prosperar a agricultura. A exceção foi para aquelas que servissem ao "uso, e vestuário dos negros, para enfardar, e empacotar fazendas, e para outros ministérios semelhantes", reforçando que "todas as mais sejam extintas e abolidas em qualquer parte onde se acharem nos meus domínios do Brasil" (ALVARÁ..., 2018, p. 27, 28). Para o pesquisador Nireu Cavalvanti, o impedimento da produção atingiu toda e qualquer fábrica, e não apenas os estabelecimentos têxteis, o que praticamente anulou ou reduziu qualquer tentativa de produção fabril no país no século XVIII (CAVALCANTI, 2004, p. 79). Embora reconhecida as limitações impostas do referido alvará, isto não impediu o discreto desenvolvimento de oficinas e manufaturas nas províncias brasileiras.

A vinda da corte e da sede do império português para o Rio de Janeiro, em 1808, significou não apenas uma mudança política e socioeconômica, mas também uma modificação de postura dos regentes. Eles precisaram adaptar as necessidades da corte à realidade e limitações administrativolegais que subordinavam o Brasil. Essa barreira, que estagnava a indústria brasileira, começou a ser rompida com o Alvará de $1^{\circ}$ de abril de 1808 , assinado pelo príncipe regente $D$. João, que declarava:

que daqui em diante seja lícito, a qualquer dos meus vassalos, qualquer que seja o País em que habitem, estabelecer todo o gênero de manufaturas, sem executar alguma, fazendo os seus trabalhos em pequeno, ou em grande, como entenderem que mais Ihes convém; para o que hei por bem derrogar o Alvará de 5 de Janeiro de 1785 (ALVARÁ..., 1808, p. 10).

Esse alvará revogou a proibição de 1785, permitindo, a partir de então, constituir fábricas e manufaturas na colônia.

Ainda que anteriormente houvesse restrições de empreendimentos fabris, a coroa não descuidou de pesquisar em seus domínios novas fontes econômicas que pudessem the trazer vantagens. A carta de Bernardo José de Lorena (1756-1818), governador de Minas Gerais, enviada em 1799 ao conde de Linhares, comprova o interesse dos governantes em conhecer a riqueza das plantas brasi-

ALMEIDA, Thais Helena de; HANNESCH, Ozana. As primeiras fábricas de papel na cidade do Rio de Janeiro no século XIX.

PÓS:Revista do Programa de Pós-graduação em Artes da EBA/UFMG. v. 11, n. 22, mai-ago. 2021 Disponível em < $\underline{\text { https://doi.org/10.35699/2237-5864.2021.25766 }>}$ 
leiras. Nela, Bernardo de Lorena informa que encarregou o Dr. Joaquim Vellozo de Miranda (17421817), professor da Universidade de Coimbra, do exame de plantas e árvores próprias para o fabrico de papel (LORENA, 1799). Em 15 de outubro de 1800, o governador encaminhou ao conde de Linhares uma lista e amostras de plantas e árvores próprias para o fabrico de papel, que foram acompanhadas de um informe do Dr. Vellozo sobre o tema. Nesta lista estão indicadas plantas nativas como a guaxiuma branca, guaxiuma ordinária, embira branca, embira vermelha, paina de embiruçu vermelho e gameleira, que "apresentaram um melhor resultado" segundo o professor, diferente das baçoura grande de folha ruiva, carrapicho, iraticu, jiquitiba, pindaíba preta, pindaíba vermelha, embiriçu branco, embiriçu vermelho, baçoura grande, embaúba, pitta e arco de pipa, que "demostraram ser rijas e intratáveis" para o fabrico do papel (LORENA, 1800). A correspondência segue até janeiro de 1801, quando Bernardo de Lorena escreve novamente ao conde de Linhares avisando que enviara as amostras de embiras com a respectiva relação de plantas assinada pelo Dr. Joaquim Vellozo de Miranda (LORENA, 1801).

A preocupação em oferecer fibras alternativas para a confecção de papel, em substituição às fibras de linho, cânhamo e algodão foi persistente. Naquela época, o conhecido papel de trapo estava escasso e caro na Europa. Assim, o assunto reaparece em um ofício expedido ao conde de Linhares, em novembro de 1809, no qual o professor e botânico brasileiro, Frei Mariano da Conceição Veloso, dizia remeter uma amostra do primeiro papel de embira (fig. 1) feito no Rio de Janeiro (VELOSO, 1809). A partir daquele ano e com o incentivo do governo português, as primeiras fábricas de papel começam a se estabelecer na cidade do Rio de Janeiro.

ALMEIDA, Thais Helena de; HANNESCH, Ozana. As primeiras fábricas de papel na cidade do Rio de Janeiro no século XIX.

PÓS:Revista do Programa de Pós-graduação em Artes da EBA/UFMG. v. 11, n. 22, mai-ago. 2021 Disponível em < $\underline{\text { https://doi.org/10.35699/2237-5864.2021.25766 }}>$ 


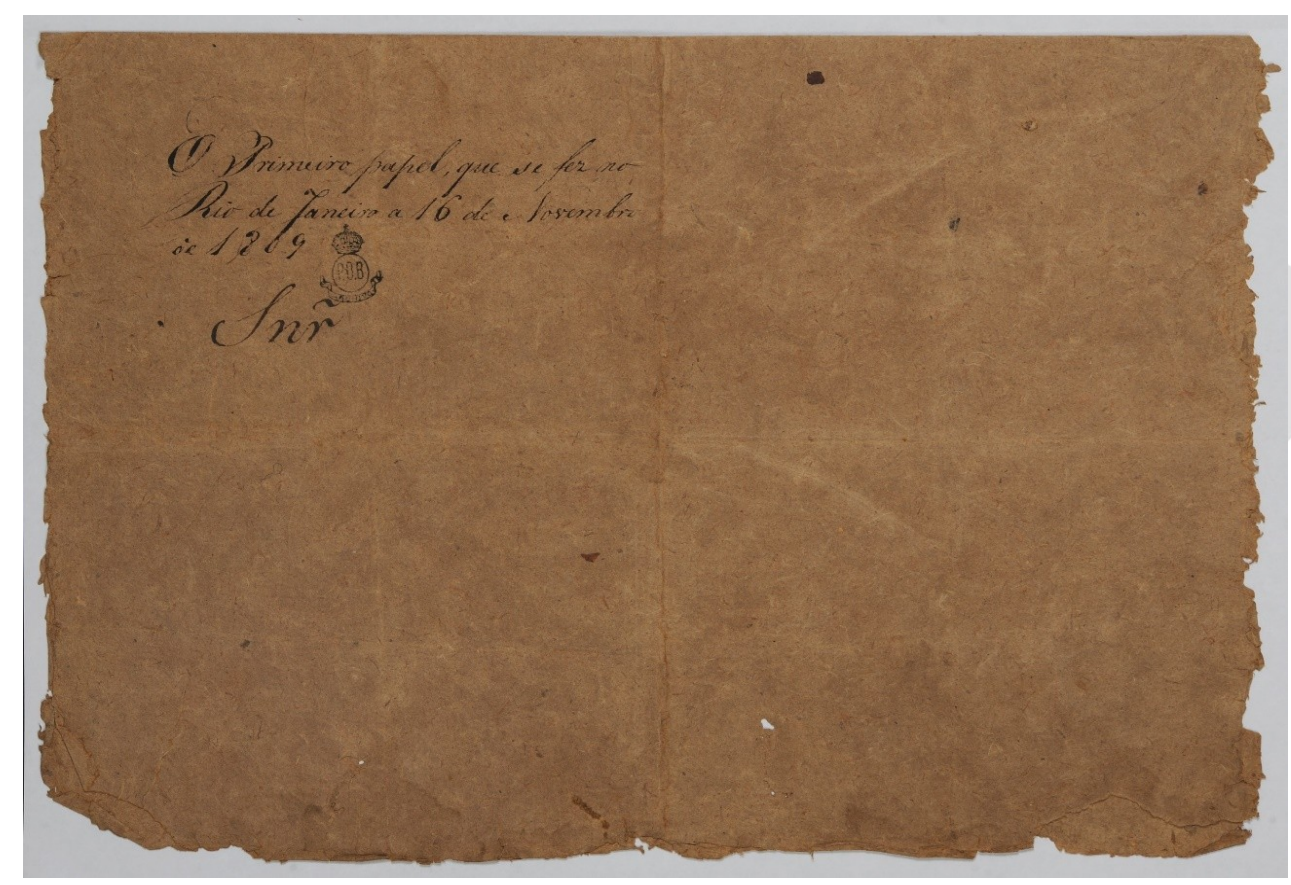

Fig. 1 - Primeiro papel produzido no Rio de Janeiro, em 16 de novembro de 1809. Fonte: Arquivo Histórico. Museu Imperial.

A maioria das publicações sobre as fábricas de papel que se desenvolveram no século XIX, no Brasil, apresentam uma visão histórica baseada na identificação de alguns proprietários e períodos de funcionamento. Não aprofundaram nas questões sobre sua implantação, problemas enfrentados para sua manutenção e matérias-primas que utilizaram. Contudo, através dos documentos primários, foi possível traçar a trajetória desses primeiros estabelecimentos na cidade do Rio de Janeiro, e, especialmente, identificar as contribuições que promoveram ou não para os avanços da fabricação do papel no Brasil, particularmente, a partir dos incentivos como as loterias e privilégios governamentais.

Embora os documentos pesquisados tenham mostrado que os primeiros investimentos da indústria papeleira aconteceram na cidade do Rio de Janeiro na década de 1810, as fábricas de papel, beneficiárias do governo, tiveram maior destaque a partir das décadas de 1830 e 1840. Fábricas estas que se estabeleceram através da importação de maquinário e mão de obra europeus, empregando, além do trapo, as fibras "indígenas", como eram chamadas as fibras da flora nativa. Entretanto, ainda no século XIX acabaram por entrar em falência e, algumas delas, foram esquecidas e apagadas da memória.

ALMEIDA, Thais Helena de; HANNESCH, Ozana. As primeiras fábricas de papel na cidade do Rio de Janeiro no século XIX.

PÓS:Revista do Programa de Pós-graduação em Artes da EBA/UFMG. v. 11, n. 22, mai-ago. 2021 Disponível em < https://doi.org/10.35699/2237-5864.2021.25766 $>$ 
Ao pesquisar sobre a implantação dessas primeiras fábricas de papel, no Rio de Janeiro, recorremos às informações de jornais, ofícios administrativos do Ministério dos Negócios do Império, correspondências, publicações, mapas geográficos e plantas arquitetônicas, pesquisados na Biblioteca Nacional, no Arquivo Nacional, no Arquivo Geral da Cidade do Rio de Janeiro, no Arquivo Histórico do Museu Imperial, em Petrópolis, e no Arquivo Ultramarino, em Lisboa. No percurso da pesquisa, algumas questões foram levantadas: de que forma esses benefícios contribuíram para o sucesso ou não desses empreendimentos? A experiência e utilização de fibras nativas impulsionaram a indústria papeleira nacional, tornando possível a substituição do papel de trapo naquele período? E qual a justificativa de as fábricas não prosperarem?

Assim, este artigo tem como objetivo relatar a implantação de algumas fábricas de papel, ocorrida entre as décadas de 1810 e 1880, na sede da corte portuguesa e posteriormente império do Brasil. Inclui também informações sobre sua produção, utilização de fibras nativas e motivos da falência, ainda que diante de um quadro favorável de incentivos por parte do governo imperial.

\section{As primeiras fábricas de papel e seus proprietários}

Para assegurar a possibilidade da implantação de indústrias fabris no Brasil, o príncipe regente D. João assinou um novo Alvará, em 28 de abril de 1809, no qual estabeleceu que, para a felicidade dos fiéis vassalos, isentava os empreendedores de pagar direitos pelas matérias-primas de uso das fábricas e indústrias (ALVARÁ..., 1809, p. 45). A medida permitiu a entrada de trapo europeu para abastecer as fábricas de papel, que não tinham matéria-prima local para colocar em andamento as máquinas e suprirem a demanda interna. Constou também no Alvará a previsão de favores pecuniários aos fabricantes. Essa deliberação veio na forma de concessão dos recursos de loterias, em benefício das "fábricas protegidas" (BRASIL, 1844). O valor arrecadado com a venda dos bilhetes era utilizado para o pagamento de prêmios e outra parte era aplicada na implantação ou melhoria da indústria, ficando o governo autorizado a exigir garantias necessárias para que tais incentivos não tivessem outra aplicação. Este benefício era solicitado à Assembleia Geral Legislativa pelos proprietários de diferentes ramos de produção, sendo analisado e votado nas sessões do órgão, e significava a garantia de estímulo para os primeiros empreendedores.

ALMEIDA, Thais Helena de; HANNESCH, Ozana. As primeiras fábricas de papel na cidade do Rio de Janeiro no século XIX.

PÓS:Revista do Programa de Pós-graduação em Artes da EBA/UFMG. v. 11, n. 22, mai-ago. 2021 Disponível em < $\underline{\text { https://doi.org/10.35699/2237-5864.2021.25766 }>~}$ 
Com os benefícios da coroa portuguesa, entre 1808 e 1811 encontramos relatos em jornais sobre a primeira fábrica de papel instalada no Andaraí Pequeno, ${ }^{1}$ zona norte do Rio de Janeiro, por iniciativa de Henrique Nunes Cardoso e Joaquim José da Silva, ambos portugueses. Os primeiros anúncios sobre a compra de trapos para uma fábrica de Estamparia e Papel no Andaraí foram publicados ainda na década de 1810. O local indicado para o negócio era um armazém na Rua Direita, n 32, atual Rua Primeiro de Março, no centro da cidade, que em 1817 anunciava comprar linho e algodão (fig. 2) (AVISOS, 1817, p. 4). Em 4 de abril do ano seguinte, o mesmo proprietário informava que compraria "todas as qualidades de retalhos, ou trapos, e as cordas de linho" para sua fábrica de papel construída no Andaraí (AVISOS, 1818, p. 4). Ao identificarmos os anúncios publicados rotineiramente ao longo de um período de anos, foi possível perceber uma infraestrutura para fazer negócios, um armazém para estocar matéria-prima e uma fábrica de papel em funcionamento, o que nos leva a inferir que se tratasse da fábrica desses proprietários mencionados.

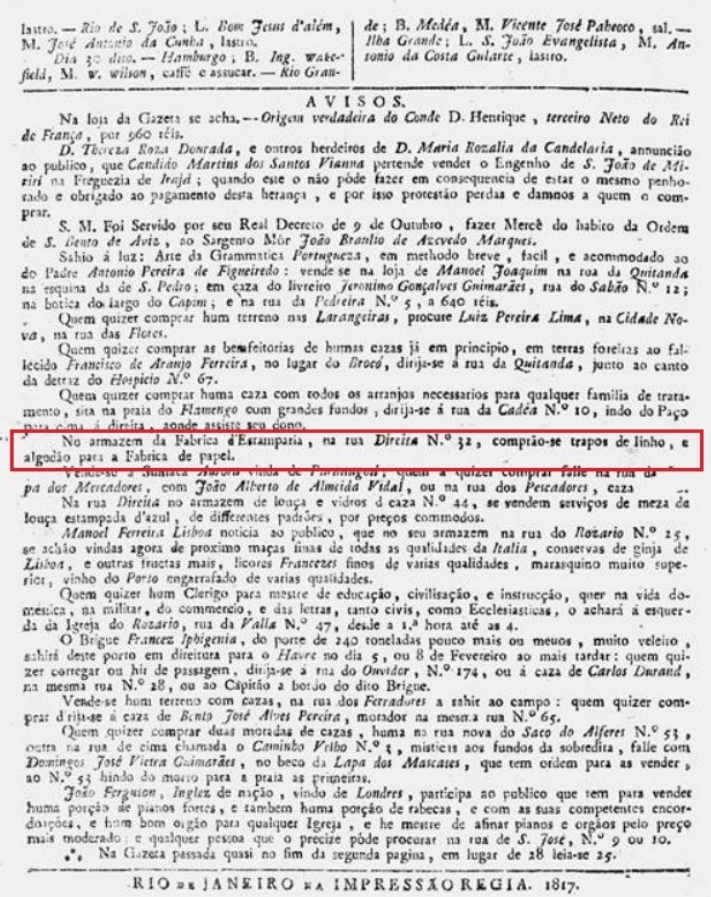

3 No armazem da Fabrica d'Escamparia, na rua Direisa N.0 32 , compräo-se trapos de linho, e algodán pasa a Fabrica de papel.

Fig. 2 - Anúncio mais antigo encontrado sobre a compra de trapos. Gazeta do Rio de Janeiro, $1^{\circ}$ de fevereiro de 1817. Fonte: Hemeroteca Digital. Fundação Biblioteca Nacional.

ALMEIDA, Thais Helena de; HANNESCH, Ozana. As primeiras fábricas de papel na cidade do Rio de Janeiro no século XIX.

PÓS:Revista do Programa de Pós-graduação em Artes da EBA/UFMG. v. 11, n. 22, mai-ago. 2021 Disponível em < $\underline{\text { https://doi.org/10.35699/2237-5864.2021.25766 }}>$ 
Em 1823 o nome de Joaquim José da Silva aparece com outros proprietários de fábricas de estamparia e papel em um documento solicitando a "Vossa Majestade Imperador" isenções para a compra de matéria-prima importada. Neste pedido, o grupo incluiu também a queixa sobre a falta de "braços livres" para trabalhar nas fábricas (REPRESENTAÇÃO..., [1823]). Além das dificuldades de ordem financeira, técnica e administrativa, esses proprietários, incluindo Joaquim José da Silva, tinham que lidar com as denúncias publicadas em jornais.

Em 1830, uma nota sobre o estado em que se encontrava uma fábrica de papel no Andaraí insinuava que, após quatro anos de existência e cinco loterias, essa ainda não havia conseguido imprimir nem os cartazes do jogo (CORRESPONDENCIA, 1830, p. 4). Três anos depois, nova nota informando que o Ministério do Império solicitava informações sobre o estado de adiantamento em que se achava a fábrica, que recebeu dez loterias em 1826, conforme o Alvará de 26 de junho do mesmo ano (MINISTERIO..., 1833, p. 4). Em função da data, infere-se que estas notícias se refiram à fábrica de Joaquim José da Silva. Todavia, ainda não encontramos documentos sobre alguma inspeção ou relatórios daquele período para esclarecer esses questionamentos.

O nome de Joaquim José da Silva ressurge, em 1838, solicitando mais 12 loterias para sua fábrica, com o objetivo de "se aplicar o seu produto aos melhoramentos, [e] aquisições necessárias para pôr em bom andamento a fábrica de papel, que tem em Andarahy" (RIO..., 1838b, p. 1). A discussão da concessão das loterias para a fábrica de Joaquim José da Silva segue durante os anos de 1838 e 1839, quando em 29 de agosto de 1839 o Diário do Rio de Janeiro publica:

Joaquim José da Silva querendo arredar de si a desagradável ideia de ser ele quem suspenda os trabalhos das suas fabricas de chitas, e papel [...], constando de máquinas, e mais utensílios em atual trabalho, se propõe vendê-las, pela falta de meios para prosperar laboração delas (NOTICIAS...,1839, p. 4).

Alguns anos depois, em 1844, esse proprietário, não tendo conseguido manter os seus negócios, anunciou a venda de suas fábricas (VENDAS, 1844, p. 3). Esta seria a última notícia encontrada nos jornais e documentos da época sobre o destino dos seus empreendimentos.

O mapa apresentado na figura 3 é um levantamento da cidade do Rio de Janeiro, entre os anos de 1826 e 1828, e indica a localização de uma fábrica de papel no Andaraí Pequeno (ALCANTARA, 1842). Pela importância na sua sinalização no mapa e repercussão nos jornais daquele período, é

ALMEIDA, Thais Helena de; HANNESCH, Ozana. As primeiras fábricas de papel na cidade do Rio de Janeiro no século XIX.

PÓS:Revista do Programa de Pós-graduação em Artes da EBA/UFMG. v. 11, n. 22, mai-ago. 2021 Disponível em < $\underline{\text { https://doi.org/10.35699/2237-5864.2021.25766 }}>$ 
provavelmente a fábrica de Joaquim José da Silva. Na imagem, é possível perceber também a distância entre o centro urbano e a região de área rural, ainda sem infraestrutura e de difícil acesso para o transporte de pessoas, onde outras fábricas, mais tarde, irão se instalar.

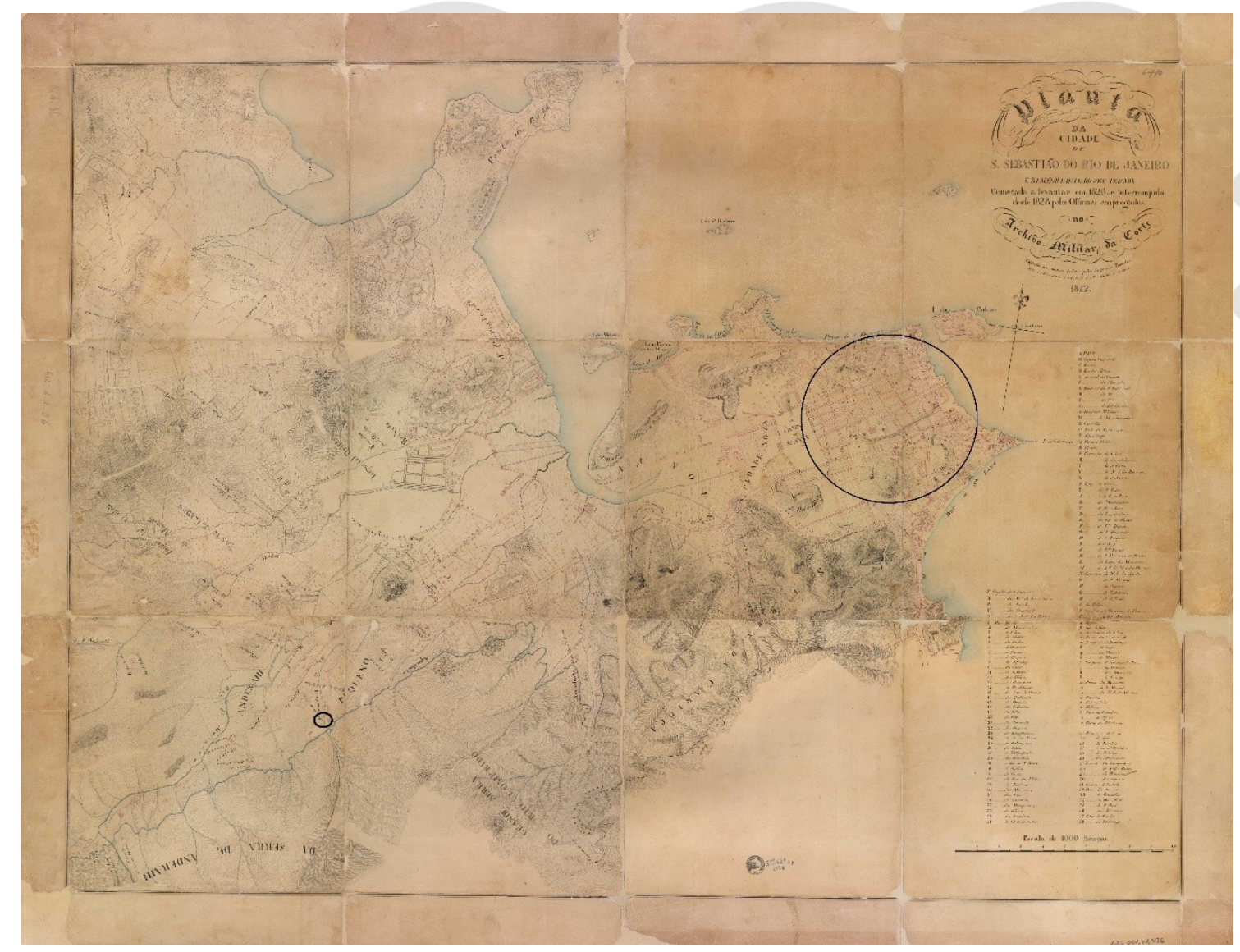

Fig. 3 - Mapa da cidade do Rio de Janeiro entre 1826 e 1828, com destaque para as áreas do centro e localização da fábrica de papel no Andaraí Pequeno. Autor: ALCANTARA, 1842. Fonte: Hemeroteca Digital. Cartografia. Fundação Biblioteca Nacional.

As fábricas de papel ajudavam a movimentar a economia da cidade, tornando-se parte integrante das notícias culturais e sociais, como se pode observar numa nota consternada de falecimento, publicada no Diário do Rio de Janeiro de 14 de janeiro de 1855, que anunciava a morte de Henri Fourdrinier. Segundo a notícia, "sua máquina de fabrico de papel contribuiu para a difusão das luzes, progresso da civilização" (FALLECIMENTO, 1855, p. 1). A exaltação parece indicar o quanto estes empreendimentos foram importantes para uma parcela da sociedade daquela época, cujo

ALMEIDA, Thais Helena de; HANNESCH, Ozana. As primeiras fábricas de papel na cidade do Rio de Janeiro no século XIX.

PÓS:Revista do Programa de Pós-graduação em Artes da EBA/UFMG. v. 11, n. 22, mai-ago. 2021 Disponível em < $\underline{\text { https://doi.org/10.35699/2237-5864.2021.25766 }>}$ 
invento da máquina de papel contínuo possibilitou um maior suprimento de papel no mercado, devido à rapidez e dimensão. A imprensa não mais estava limitada às formas de fazer papel à mão e, consequentemente, isso favoreceu uma maior produção e circulação de livros, documentos e ideias.

\section{Os papeleiros André Gaillard e Zeferino Ferrez}

Dos papeleiros pesquisados, dois proprietários se destacam entre as décadas de 1830 e 1840: André Gaillard e Zeferino Ferrez. Embora este artigo esteja baseado em documentos e diversos periódicos da época, foi um suplemento do Jornal do Commercio de 17 de outubro de 1845 (AO PUBLICO, 1845a, p. 1-2) que possibilitou ampliar e compreender a importância destes empreendedores em relação à produção e ao investimento material e humano nas fábricas, bem como identificar uma rivalidade entre eles, ainda que esta pesquisa apresente um resultado parcial do tema.

As primeiras informações, em 1831, sobre o francês André Gaillard, nascido em Toulouse, França, informavam que ele adquirira um antigo moinho, no Andaraí, para transformá-lo em fábrica de papel. Lá, tentou aproveitar a construção e parte do maquinário existente; mas com um sistema antigo e defeituoso não conseguiu alcançar o resultado que esperava. Assim, em 1833 viajou para a Inglaterra e para a França a fim de buscar meios para melhorar seu empreendimento. Após dois anos, trouxe de Castres, França, não só uma máquina, mas um operário carpinteiro e papeleiro, Frederico Bel, para montar o maquinário e trabalhar. No entanto, tempos depois, esse empregado abandonou o contrato e fez sociedade com o francês Zeferino Ferrez, nascido em Saint-Laurent, que também havia trabalhado para a fábrica de André Gaillard (AO PUBLICO, 1845a, p. 1).

Os novos sócios, Zeferino Ferrez e Frederico Bel, trataram logo de encaminhar um requerimento à Câmara dos Deputados, em 1838, com o propósito de impulsionar os negócios, afirmando terem sido eles os primeiros introdutores da fabricação de papel no Brasil, e por isso solicitavam a concessão de loterias, como as oferecidas a André Gaillard e a Joaquim José da Silva (RIO..., 1838a, p. 1). Não foi possível até o momento saber se tiveram êxito no seu intento. Entretanto, infere-se que a sociedade entre eles não tenha durado, pois, no início dos anos de 1840, Zeferino Ferrez

ALMEIDA, Thais Helena de; HANNESCH, Ozana. As primeiras fábricas de papel na cidade do Rio de Janeiro no século XIX.

PÓS:Revista do Programa de Pós-graduação em Artes da EBA/UFMG. v. 11, n. 22, mai-ago. 2021 Disponível em < $\underline{\text { https://doi.org/10.35699/2237-5864.2021.25766 }}>$ 
comprou um terreno na vizinhança da fábrica de André Gaillard para montar sua fábrica independente (AO PUBLICO, 1845a, p. 1). A compra, efetivada em 26 de janeiro de 1841, constava de "uma chácara e suas benfeitorias, com casas de vivenda e mais árvores" (FERREZ, 1967, p. 25-26).

Muitas intrigas e discussões envolveram André Gaillard, Zeferino Ferrez e outros papeleiros, algumas das quais serão apresentadas ao longo deste artigo. As notícias veiculadas nos jornais se referem às disputas e aos esforços para manter seus investimentos, onde a dificuldade de conseguir matéria-prima, mão de obra especializada e infraestrutura (como estradas, água encanada etc.) tornavam o trabalho ainda mais árduo.

O discurso proferido pelo conde de Gestas, publicado no Pharol do Império, em 1837, traz um elogio a André Gaillard e uma crítica à situação de outra fábrica no Andaraí, que teria recebido muitas loterias, mas não tivera maiores resultados com o empreendimento. A localização e data da publicação parecem indicar a referida fábrica como de propriedade de Joaquim José da Silva, que havia recebido, até então, 22 loterias do governo. De acordo com o conde de Gesta, “o Sr. Gaillard teria construído uma fábrica de papel e papelão no mesmo Andaraí, com um sistema mais moderno, movendo o maquinário com água e com maior perfeição" (VARIEDADES, 1837, p. 3). O conde de Gesta menciona ainda que André Gaillard estaria procurando fibras indígenas em substituição ao trapo, experimentando a arrowroot, planta conhecida como araruta.

É prematuro afirmar que ele teria conseguido produzir papel com fibras de araruta para suprir a demanda interna, entretanto seus esforços provavelmente tiveram sucesso, pois iniciou o fornecimento de seu papel para o jornal O Parlamentar e o Despertador. Em uma nota "A favor da Indústria”, o Diário do Rio de Janeiro, de 13 de setembro de 1838, anunciava: “Devemos dizer que não é perfeito, nem a perfeição se alcança de um salto [mas] os esforços de um homem, sua atividade e boa vontade não podem ir muito avante, vendo-se, como se vê o Sr. Gaillard reduzido aos seus meios e recursos" (FAVOR..., 1838, p. 916). Esta defesa rendeu a André Gaillard, naquele ano, a concessão de oito loterias para serem aplicadas à conservação e aumento da fábrica de papel estabelecida em Andaraí Pequeno (RIO..., 1838c, p. 1).

ALMEIDA, Thais Helena de; HANNESCH, Ozana. As primeiras fábricas de papel na cidade do Rio de Janeiro no século XIX.

PÓS:Revista do Programa de Pós-graduação em Artes da EBA/UFMG. v. 11, n. 22, mai-ago. 2021 Disponível em < $\underline{\text { https://doi.org/10.35699/2237-5864.2021.25766 }}>$ 
Confirmando o uso do papel de produção nacional na publicação dos jornais, um dia antes, em 12 de setembro de 1838, O Parlamentar faz uma nota, informando que a fábrica de André Gaillard, além de ter fornecido papel para dois outros jornais, teria suprido este jornal para que não interrompesse três edições (O PARLAMENTAR..., 1838, p. 93). A notícia abaixo (fig. 4) dá destaque ao feito de André Gaillard, bem como reforça a dificuldade de resposta do comércio à demanda de papel para impressão na época.

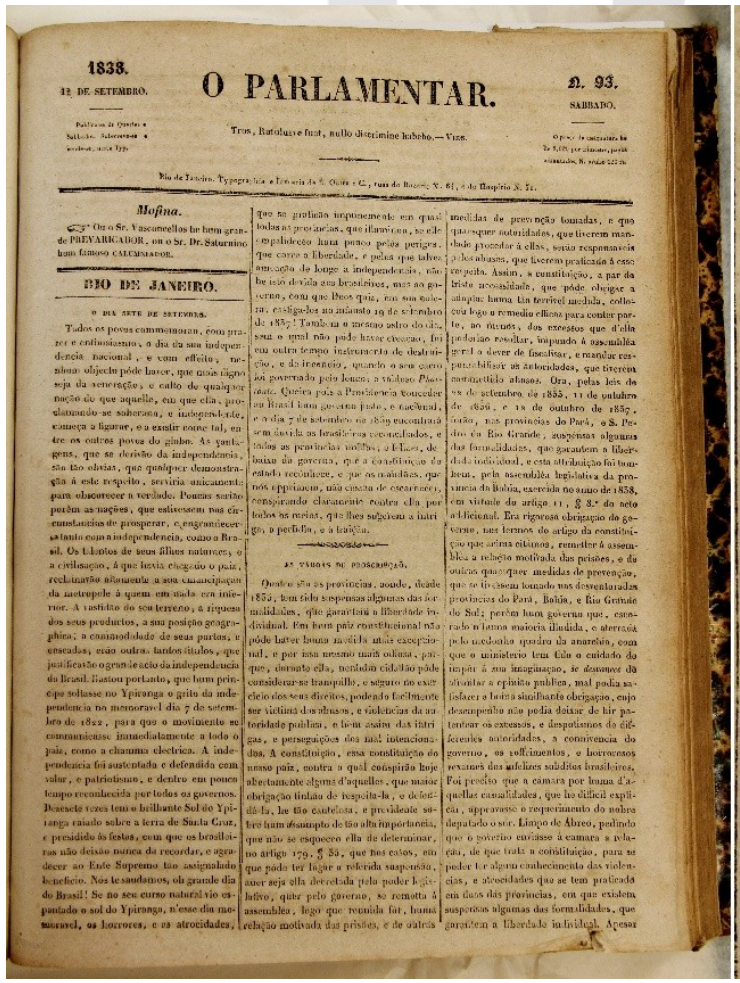

\section{- Parlamentar impresso em papel nacional.}

O snr. André Gailhard, que estava jú fornecendo papel para dous jornaes d'esta capital, teve tambem a complacencia de se exforçar para of fornecer para esta folha: e assim póde affirmar-se, que ao snr. André Gailhard deve a nossa imprensa o grande serviço de nāo teren cessado tres publicaçōes periodicas.

Este facto deve fazer reflectir sobre o perigo de nāu tèr-mos entre nós em grande escala, liumá manufactura tāo neees. saria; perigo que poderia tornar-se muito mais grave, se viessemos a soffrer hum blogueio de que ha exemplos presentes em nosso cointinente. Nós, mais ainda por interesse geral, do que gratidão á officiosidade do benemerito industrioso, recommendamos o sea estabelecimento ao favor do publico.

Fig. 4- Jornal O Parlamentar, de 12 de setembro de 1838, e detalhe da nota, no verso da página 93, saudando os esforços de André Gaillard na produção de papel nacional. Fonte: Divisão de Obras Raras. Fundação Biblioteca Nacional. Foto: Thais Almeida, 2019.

Apesar de seu empenho para encontrar um substituto para o papel de trapo, André Gaillard continuou importando matéria-prima da Europa, como consta na autorização de fevereiro de 1839, em que o inspetor da Alfândega autoriza despachar, livre de diretos de impostos, 1.200 libras de trapo para a fábrica (MINISTERIO..., 1839, p. 142).

ALMEIDA, Thais Helena de; HANNESCH, Ozana. As primeiras fábricas de papel na cidade do Rio de Janeiro no século XIX.

PÓS:Revista do Programa de Pós-graduação em Artes da EBA/UFMG. v. 11, n. 22, mai-ago. 2021 Disponível em < https://doi.org/10.35699/2237-5864.2021.25766 $>$ 
Por sua vez, Zeferino Ferrez também trabalhava para pedir proteção para sua nova fábrica e oferecia amostras de papel fabricado com matéria-prima de fibras indígenas, sem identificá-las. $O$ fato foi registrado em ata da Câmara do Senado, do dia 17 de junho de 1839 (CÂMARA..., 1839, p. 1). Embora alegasse o uso de tal matéria-prima, ele continuava a comprar trapo da Europa, conforme informações da inspetoria da Alfândega, em 1840, que permitiu o despacho livre de impostos de 12 fardos de trapo, com peso de "6 quintaes" para sua fábrica de papel (MINISTERIO..., 1840, p. 234).

Para melhorar seu empreendimento, em 1842, André Gaillard fez novo pedido de auxílio ao governo para Ihe conceder mais quatro loterias e, em 1843, embarcou novamente para a Europa, voltando em 1844. Ao retornar, trouxe operários europeus e uma máquina capaz de fazer papel contínuo, comprada de Ferdinand Leistenschneider, inventor francês, sediado na cidade de Poncey, região de Dijon. Segundo informações da Sociedade Auxiliadora da Indústria Nacional, publicadas no Suplemento do Jornal do Commercio, de 1845, André Gaillard adquiriu outra chácara, com maior fluxo de água para movimentar seu novo equipamento. Esta nova fábrica consistia em um edifício de três andares, grande e em bom estado, com maquinário para fazer papel e papelão pelo sistema mais moderno, cujo motor era movido por água, que girava uma roda hidráulica pequena, fazendo andar todo o equipamento com grande velocidade. $O$ texto descreve que o empreendedor produziu papéis com grande resultado e uma rara perfeição na execução (AO PUBLICO, 1845a, p. 12). A fábrica manteve sua produção, ainda que com alguns imprevistos, pois a peça que convertia a massa em papel não trabalhava regularmente. Este fato não impediu que André Gaillard encaminhasse ao "Governo duas amostras do papel; um inferior que serve para embrulho, e outro de melhor qualidade", em que se poderia imprimir jornais. Contudo, era opinião de alguns que os equipamentos não se prestavam ao fabrico de papéis de boa qualidade (RELATORIO..., 1847, p. 2728). Para o autor Gilberto Ferrez (1967, p. 28), D. Pedro II teve uma impressão diferente ao visitar a fábrica, em 14 de maio de 1848, pois o imperador teria deixado o local satisfeito com o que vira.

A busca por um papel alternativo, que pudesse suprir a demanda interna e dar independência ao país, e os problemas políticos e econômicos nacionais, que atrapalhavam a importação e compra de trapo, geraram uma disputa entre André Gaillard e Zeferino Ferrez, como identificado no Suplemento do Jornal do Commercio de 1845. Nele, André Gaillard contesta as amostras de papel de fibras indígenas apresentadas por Zeferino Ferrez, pois, segundo ele, este papeleiro precisaria de

ALMEIDA, Thais Helena de; HANNESCH, Ozana. As primeiras fábricas de papel na cidade do Rio de Janeiro no século XIX.

PÓS:Revista do Programa de Pós-graduação em Artes da EBA/UFMG. v. 11, n. 22, mai-ago. 2021 Disponível em < $\underline{\text { https://doi.org/10.35699/2237-5864.2021.25766 }>}$ 
melhor maquinário para produzir um papel de qualidade que pudesse competir com a indústria europeia, e isto, conforme Gaillard, Ferrez nem ao menos provou ter conseguido (AO PUBLICO, $1845 a$, p. 1). Essa é uma das discussões que fundam o conflito entre esses concorrentes.

Assim como André Gaillard, Zeferino Ferrez se empenhou para aumentar sua produção, ampliando o edifício principal e embarcando para a França, em 1847, a fim de comprar maquinário (ASSEMBLÉA..., 1847, p. 32). A chácara do Andarai Pequeno tinha uma casa e uma fábrica, constituída de um edifício de três andares, construído com grandes e grossas muralhas do lado do rio, possivelmente à semelhança da organização européia para os moinhos tradicionais de papel, que incluia um andar para as etapas de fabricação, outro para moradia e o último, mais ventilado, para a secagem dos papéis. A máquina de fazer papel foi adquirida em 17 de junho da empresa de $M$. Casimir Chapelle (FERREZ, 1967, p. 29-30).

Mesmo com estes investimentos, os trabalhos de ampliação e modernização do empreendimento não avançaram como esperado. Um relatório da Repartição dos Negócios do Império, em 1848, registrou os atrasos na melhoria de sua fábrica de papel, informando que o edifício tinha 110 palmos de comprimento por 75 de largura, mas Ihe faltava concluir metade do telhado, embora dispusesse de material para fazê-lo. O maquinário ainda estava encaixotado e não havia sido instalado, por falta de conclusão do espaço. Esse relatório trazia informações sobre o maquinário, descrevendo o mecanismo, que era movido por roda hidráulica de 38 palmos de diâmetro, sendo uma máquina contínua e, segundo o texto, superior à máquina contínua redonda de André Gaillard (RELATORIO..., 1848, p. 28).

Conciente de que o prédio não estava de todo concluído e as máquinas ainda por terminar de montar, Zeferino Ferrez esperava empregar, em 1848, de 80 a 90 pessoas e fornecer 3.000 libras de papel por dia (FERRREZ, 1967, p. 28). O desenho abaixo (fig. 5) ilustra as dimensões da fábrica e da roda d'água, e permite entender o tamanho do investimento assumido pelo papeleiro.

ALMEIDA, Thais Helena de; HANNESCH, Ozana. As primeiras fábricas de papel na cidade do Rio de Janeiro no século XIX.

PÓS:Revista do Programa de Pós-graduação em Artes da EBA/UFMG. v. 11, n. 22, mai-ago. 2021 Disponível em < $\underline{\text { https://doi.org/10.35699/2237-5864.2021.25766 }>~}$ 


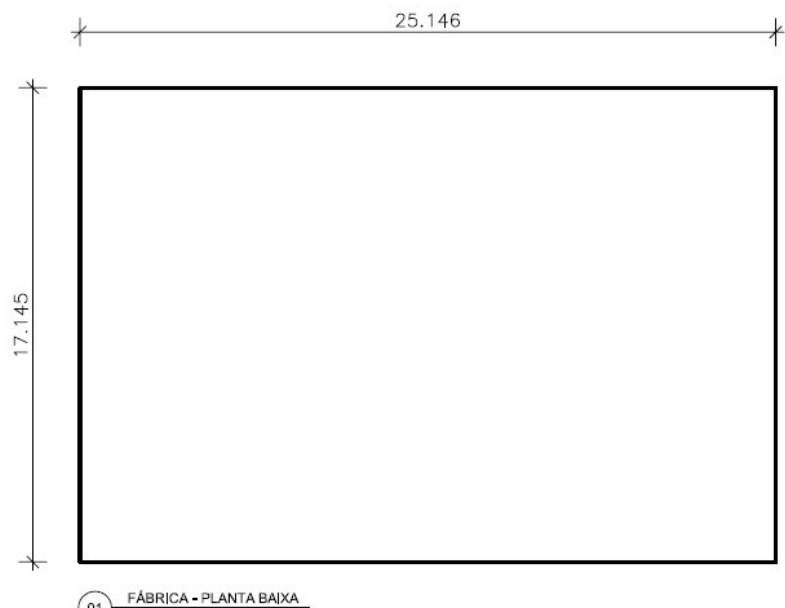

(01) FÁBRICA-PLANTA BAIXA

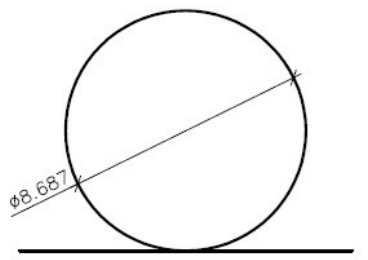

(02) RODA DÁGUA-VISTA

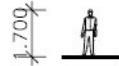

(03) ESCALA HUMANA

Fig. 5 - Desenho esquemático das escalas do ser humano e do edifício e roda d'água da fábrica de Zeferino Ferrez. Autor: Beatriz Slaibi, arquiteta e urbanista, 2016.

Os desafios industriais brasileiros eram muitos em meados do século XIX: investimentos, matériaprima, mão de obra, concorrência, compromissos e prazos. Entretanto, a vida impôs desafios ainda maiores a estes dois empreendedores. Quase cego e deprimido André Gaillard cometeu suicídio na noite de 31 de dezembro de 1848, dentro de uma embarcação para cargas e passageiros, na Baía de Guanabara (O DIARIO, 1849, p. 3). Zeferino Ferrez e sua esposa morreram repentinamente em 1851, juntamente com dois escravos e toda a criação da chácara, o que levantou suspeita de crime por envenenamento. Naquela circunstância, o cônsul francês pediu um exame médico-legal, o qual não encontrou nada de suspeito, confirmando apenas o diagnóstico de disenteria (FERREZ, 1967, p. 29).

Na tentativa de salvar a fábrica de André Gaillard, Januária Gaillard, sua viúva, encaminhou à Comissão de Fazenda um documento pedindo que fosse isenta do pagamento dos produtos das quatro loterias concedidas a seu marido. O pedido, entretanto, foi indeferido (RIO..., 1850b, p. 2). Sem condições de cumprir o compromisso e pagar a dívida, os "arrendamentos da fábrica de papel"

ALMEIDA, Thais Helena de; HANNESCH, Ozana. As primeiras fábricas de papel na cidade do Rio de Janeiro no século XIX.

PÓS:Revista do Programa de Pós-graduação em Artes da EBA/UFMG. v. 11, n. 22, mai-ago. 2021 Disponível em < $\underline{\text { https://doi.org/10.35699/2237-5864.2021.25766 }}>$ 
foram anunciados e encaminhados para serem "arrematados em praça" (ANNUNCIOS, 1854, p. 3). Inferimos que essa transferência de proprietário não tenha ocorrido e que Januária Gaillard continuou a frente da fábrica, com uma produção de papel ordinário maior que o da fábrica de Zeferino Ferrez, segundo informou o relatório da Repartição dos Negócios do Império, em 1856 (RELATORIO..., 1857, p. 116). Um ano mais tarde, o arrendamento da fábrica volta a ser notícia nos jornais para ser arrematado "em última praça os aluguéis da fábrica de fazer papel com os seus pertences para o fabrico, movida por água e montada em uma bem construída casa" (PUBLICAÇOES..., 1857, p. 2). Em novas tentativas de reverter o processo, Januária Gaillard encaminhou outros pedidos à Comissão de Fazenda, para que perdoasse a dívida contraída com as loterias (ASSEMBLEIA..., 1858, p. 2). As informações sobre estes pedidos e o arrendamento da fábrica deixaram de circular nos jornais.

Os esforços para manter a produção da fábrica de Zeferino Ferrez e mesmo quem teria assumido essa tarefa são ainda menos conhecidos. Mas anos depois do falecimento do proprietário, o mesmo relatório da Repartição dos Negócios do Império, que informava sobre o andamento da fábrica de André Gaillart, descrevia também que a fábrica de Zeferino Ferrez ainda trabalhava com máquinas movidas a água e produzia diariamente, em média, 32 resmas de papel ordinário (RELATORIO..., 1857 , p. 116). As informações sobre o funcionamento e produção dessas fábricas desaparecem dos relatos voltando a ser citadas em 1862. Entretanto as informações são contraditórias, conforme consta no Boletim do Expediente do Governo, ligado ao Ministério da Fazenda, que publicou:

As duas fábricas de papel de Zeferino Ferrez e André Gaillard, com o falecimento de seus proprietários, deixaram de trabalhar e se acham hoje em completo abandono e ruina. No senado existem minuciosas informações a este respeito nas petições dos herdeiros daqueles proprietários, requerendo dispensa do pagamento da dívida proveniente do benefício das loterias (MINISTERIO..., 1862b, p. 9-10).

Depois desta menção, as informações sobre o destino das instalações das fábricas e do moderno maquinário vindo da Europa se tornaram escassas nos jornais da época. Uma indicação de que estas fábricas teriam deixado de funcionar aparece no levantamento "Nova numeração dos prédios da cidade do Rio de Janeiro", realizado por João Cruvello Cavalcanti, em 1878. Na parte dedicada aos imóveis e terrenos da "Estrada Nova da Tijuca", o número 11 (antigo 9) é citado como herança de Zeferino Ferrez e que, na avaliação de Cavalcanti, encontrava-se arruinado. Um terreno com uma

ALMEIDA, Thais Helena de; HANNESCH, Ozana. As primeiras fábricas de papel na cidade do Rio de Janeiro no século XIX.

PÓS:Revista do Programa de Pós-graduação em Artes da EBA/UFMG. v. 11, n. 22, mai-ago. 2021 Disponível em < $\underline{\text { https://doi.org/10.35699/2237-5864.2021.25766 }>}$ 
construção de 13 quartos, pertencente aos herdeiros de André Gaillard, também foi indicado na mesma região, no número 176 (antigo 52) da rua Conde de Bonfim, no Andaraí Pequeno (CAVALCANTI, 1878, p. 877-882). Quanto ao uso destes logradouros, Cavalcanti não faz menção alguma de que seriam usados como áreas de fábricas. As lembranças desta área industrial foram apagadas com a expansão urbana do bairro da Tijuca, deixando rastros para serem seguidos e localizados em reconhecimento desta memória.

\section{Outros empreendedores da indústria papeleira}

Na década de 1840, mesmo com todas as dificuldades apresentadas, outros empreendimentos papeleiros começam a surgir na cidade do Rio de Janeiro, sobretudo na região do Andaraí e da Cidade Nova. Assim, em 1845, identificamos o nome de Joaquim da Cruz Lima como proprietário de uma fábrica na Tijuca e morador da rua São Pedro, n 88, na Cidade Nova (NOT. ..., 1845, p. 4). Em 1846, Cruz Lima é citado como tendo encaminhado requerimento à Comissão de Fazenda, em que pedia quatro loterias para sua fábrica de papel e papelão (RIO..., 1846a, p.1). Na ata da sessão da Câmara dos Deputados de 13 de fevereiro de 1850, o parecer sobre seu requerimento foi aprovado e encaminhado à Comissão do Comércio, Indústria e Artes (RIO..., 1850a, p. 2), entretanto, pouco se sabe desta fábrica e, até o momento, nenhum documento foi localizado sobre ela.

O francês João Constant foi identificado como papeleiro por meio de uma carta direcionada ao público no Jornal do Commercio, em 21 de outubro de 1845. Nela, o autor se defende de acusações feitas por André Gaillard, e afirma ter sido ele o primeiro fabricante de papel do Brasil, entre os anos de 1827 e 1829 (AO PUBLICO, 1845b, p. 1). A partir desse ano foram localizadas referências sobre o encaminhamento de requerimentos de João Constant à Comissão de Fazenda, solicitando loterias para, com o produto delas, montar uma fábrica de papel. No texto, de 1846, ele declarava ter-se habilitado para fabricar papel "nas primeiras fábricas de França, do que já tem apresentado bastante provas" de sua capacidade. No entanto, a comissão não atendeu ao seu pedido "por não ser mais admissível a multiplicação de tais concessões" (RIO..., 1846b, p. 1). Porém, o papeleiro não se dá por vencido e, em 1847, volta com novo pedindo de loterias para estabelecer sua fábrica de papel, tendo igualmente seu pedido negado (RIO..., 1847, p. 2). Ainda não foi possível verificar se ele conseguiu apoio financeiro, se chegou a erguer, de fato, sua fábrica e onde ela se localizava.

ALMEIDA, Thais Helena de; HANNESCH, Ozana. As primeiras fábricas de papel na cidade do Rio de Janeiro no século XIX.

PÓS:Revista do Programa de Pós-graduação em Artes da EBA/UFMG. v. 11, n. 22, mai-ago. 2021 Disponível em < $\underline{\text { https://doi.org/10.35699/2237-5864.2021.25766 }}>$ 
Também da década de 1840, o nome de Manuel Borges Homem é mencionado como proprietário de fábricas, sendo uma delas, de papel. Em uma sessão da Câmara Municipal consta o registro de aprovação, em 1846, de seu pedido de licença para a instalação da fábrica de papel na serra de Andaraí Grande, ${ }^{3}$ após vistoria do fiscal do Engenho Velho (CAMARA..., 1849, p. 5). Do andamento e produção desta fábrica de papel não se tem muitas informações. Entretanto, o Boletim do Expediente do Governo, de 1862, publicou notícia de uma negociação com Manuel Borges Homem, o qual pedia uma indenização pela privação, três meses por ano, das águas de sua chácara, que serviam de motor para as máquinas das fábricas no Andaraí Grande, para suprir o abastecimento de água na cidade. Para tentar resolver o problema, o inspetor geral de obras públicas visitou o local da fábrica de papel para verificar a necessidade do Estado de comprá-la e o seu terreno, com as fontes de água (MINISTERIO..., 1862a, p. 25). A solução para esta tratativa parece ter se arrastado por anos, pois num relato do corpo legislativo do Senado, de 8 de outubro de 1869, ainda pairava dúvida sobre esta compra e sobre o valor do negócio, que naquele momento estavam sendo tratados com a viúva do proprietário (SENADO, 1869, p. 1-2).

Em meio a publicidade sobre um empreendimento de 1856, noticiando a construção de um cemitério para animais na Praia Vermelha, se descreve que o terreno era situado atrás de uma fábrica de papel, na praia do Suzano, atual bairro da Urca. A localização desta fábrica pode ser identificada em um mapa de 1870-1875 (PLANTA..., 1870). Tratava-se de uma fábrica de papel pintado ${ }^{4}$, a Imperial Fábrica de Santa Maria, de propriedade de Caetano Antonio Gonsalves Garcia, inspecionada, em 1855, pela "Comissão de Indústria Manufactureira". Esta Comissão relatou que embora a fábrica não estivesse "no pé" das principais fábricas de Paris, Berlim e Londres, "três grandes e artísticas capitais da Europa civilizada", tinha potencial para se desenvolver no país (SOCIEDADE..., 1855, p. 42).

Outros nomes irão surgir nos jornais e documentos, como na transcrição da ata da Sociedade Auxiliadora da Indústria Nacional em 1887. No texto, há discussão de um abaixo-assinado propondo para sócios efetivos os fabricantes de papel e papelão José Ribeiro da Silva, José Pereira Gomes de Oliveira e José da Silva Araújo, "todos com fábricas estabelecidas na Serra da Tijuca e com depósito à rua do Rosário no 96" (SOCIEDADE..., 1887, p. 146). Destes proprietários, José da Silva Araújo parece ter sido o mais proeminente, garantindo a ele lugar de destaque na publicação da empresa de papel Companhia Melhoramentos de São Paulo, com data sugerida de 1926. No capítulo intitu-

ALMEIDA, Thais Helena de; HANNESCH, Ozana. As primeiras fábricas de papel na cidade do Rio de Janeiro no século XIX.

PÓS:Revista do Programa de Pós-graduação em Artes da EBA/UFMG. v. 11, n. 22, mai-ago. 2021 Disponível em < $\underline{\text { https://doi.org/10.35699/2237-5864.2021.25766 }}>$ 
lado "Notas sobre as origens historicas da fabricação do papel no Brasil e seu desenvolvimento", o texto indica que "existem na Tijuca quatro fábricas de papel, uma das quais, do Sr. José da Silva Araújo, vem sendo por ele aparelhada para suprir os mercados internos desde 1883" (CENTRO..., [1926?], p. 37-39). Nesta publicação foi incluída uma fotografia da fábrica de José da Silva Araújo, em 1887. A figura 6 abaixo apresenta parte dos edifícios que compunham o empreendimento fabril, os empregados, famílias e as carroças com matéria-prima para a fabricação do papel.

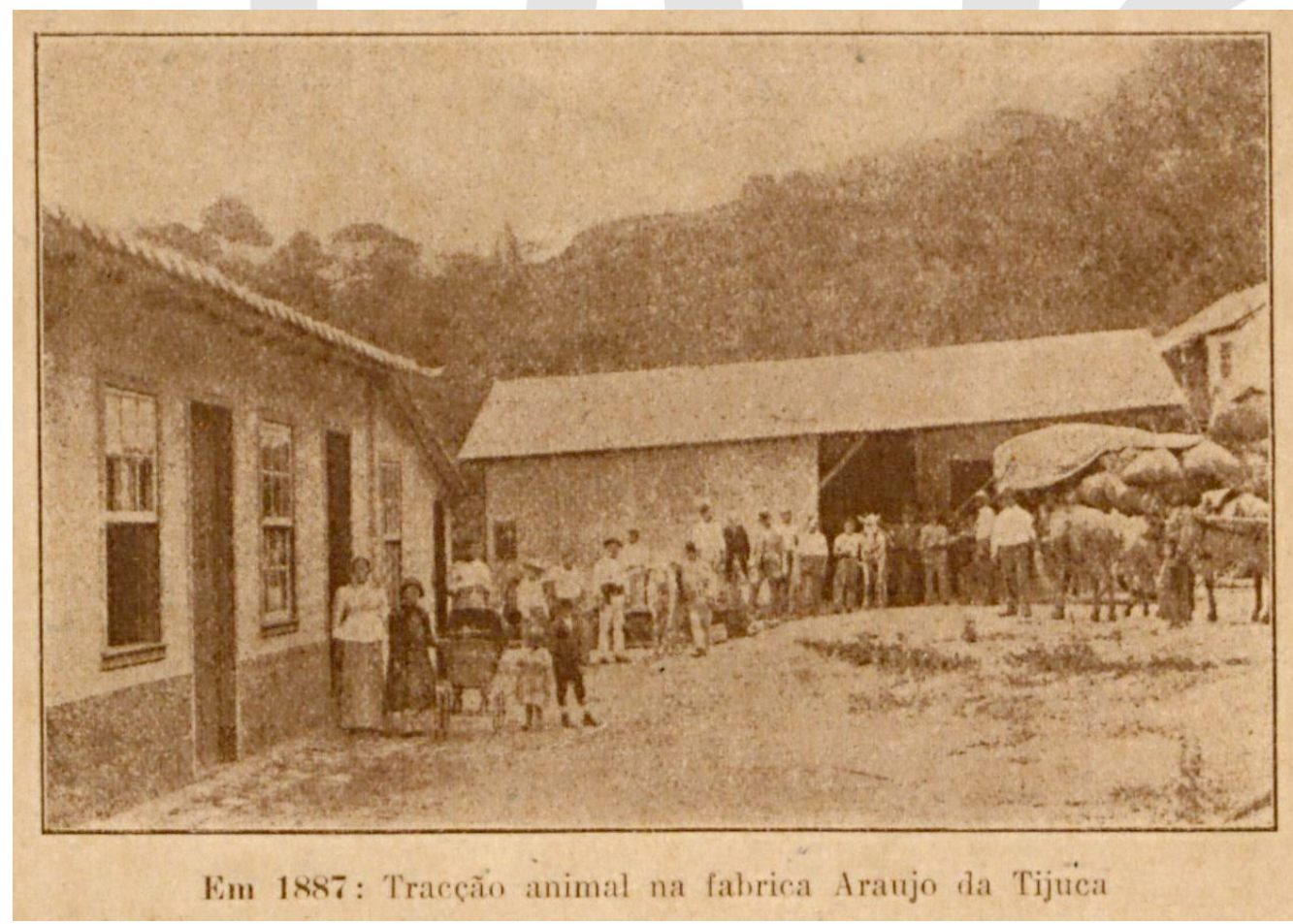

Fig. 6 - Vista da fábrica de José da Silva Araújo em 1887, na Serra da Tijuca. Fonte: CENTRO..., [1926?], p. 4041.

Para além da expansão das fábricas de papel na região da Tijuca e do Andaraí, outras fábricas e depósitos foram se estabelecendo no centro da cidade. Entre os anos de 1837 e 1855, os jornais do Rio de Janeiro publicaram anúncios com endereços de fábricas de papelão, caixas, papel de embrulho e depósitos. Em sua maioria, esses anúncios não informavam o nome de seus proprietários, os quais frequentemente usavam os jornais para divulgar o funcionamento de suas fábricas, a compra e venda dos produtos e matéria-prima, confirmando um crescente e importante comércio a se firmar no Rio de Janeiro. Por ser o centro da cidade uma região que não oferecia um volume

ALMEIDA, Thais Helena de; HANNESCH, Ozana. As primeiras fábricas de papel na cidade do Rio de Janeiro no século XIX.

PÓS:Revista do Programa de Pós-graduação em Artes da EBA/UFMG. v. 11, n. 22, mai-ago. 2021 Disponível em < $\underline{\text { https://doi.org/10.35699/2237-5864.2021.25766 }}>$ 
elevado de água capaz de fazer rodar o maquinário de uma fábrica de papel, a suposição é de que estas fábricas seriam de papel reciclado, que utilizavam um processo mais simples de produção, demandando um volume de água menor.

Para uma melhor compreensão e visualização desses empreendimentos, o mapa de 1852, apresentado na figura 7, mostra um levantamento realizado para indicar as fábricas de papelão, caixas, papel de embrulho e depósitos de papel, segundo informações retiradas dos jornais do período mencionado.

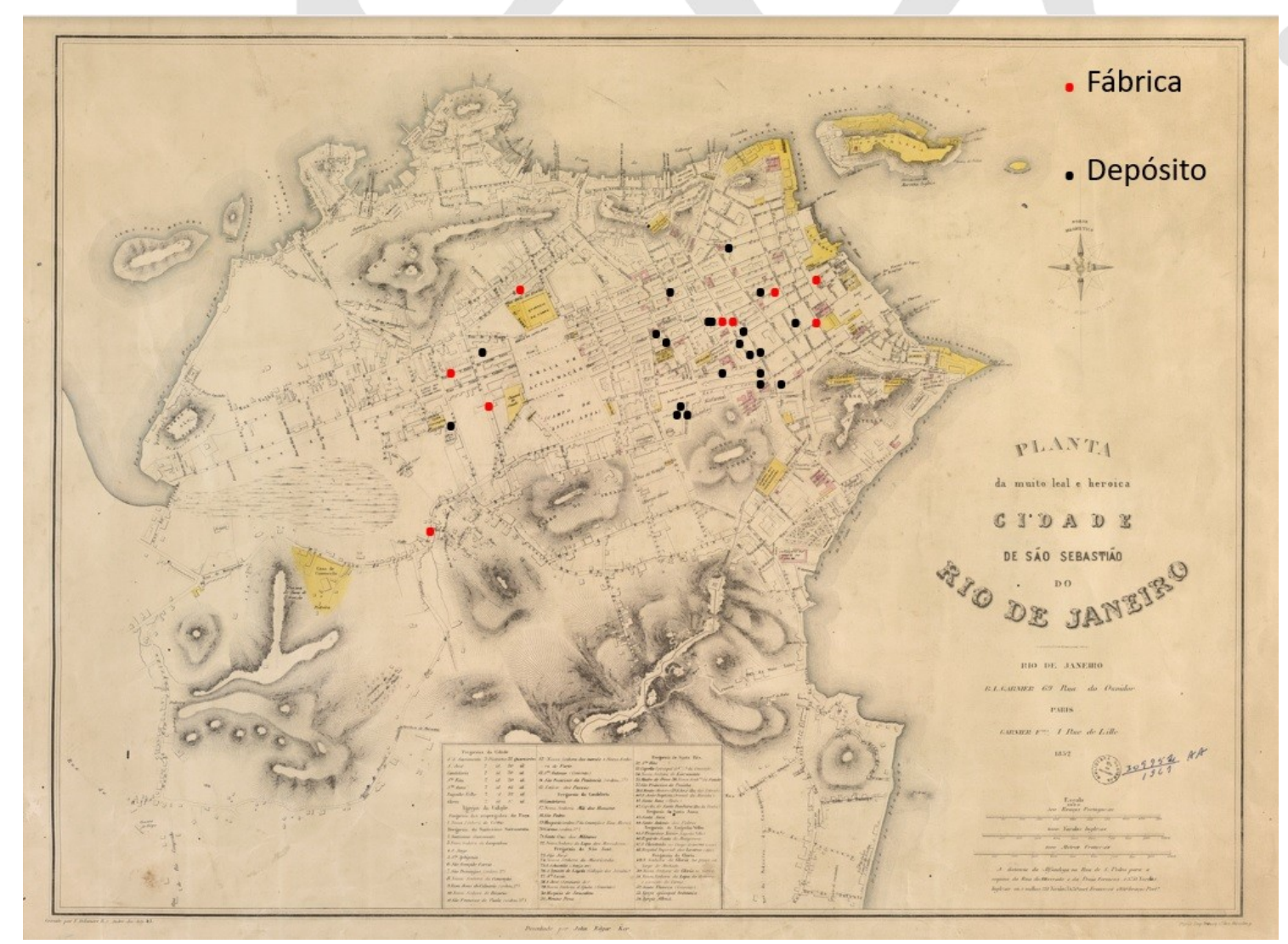

Fig. 7-Planta da cidade do Rio de Janeiro, levantada em 1852, com a localização das fábricas e depósitos de papel entre 1837 e 1855 (PLANTA..., 1852). Fonte: Fundação Biblioteca Nacional. Interferência elaborada pelas autoras.

A indústria papeleira na cidade do Rio de Janeiro acabou por incentivar outros empreendedores em diversas províncias no país. Um breve levantamento destas fábricas aponta para o interesse de brasileiros e estrangeiros de investirem nas regiões Nordeste, Sudeste e Sul do país e utilizar uma

ALMEIDA, Thais Helena de; HANNESCH, Ozana. As primeiras fábricas de papel na cidade do Rio de Janeiro no século XIX.

PÓS:Revista do Programa de Pós-graduação em Artes da EBA/UFMG. v. 11, n. 22, mai-ago. 2021 Disponível em < https://doi.org/10.35699/2237-5864.2021.25766 $>$ 
variedade de fibras a partir de plantas nativas como a araruta, o coco, o milho, a guanxuma e o gravatá. Fibras de bananeira, cana-de-açúcar e madeira também integram os documentos de pedidos de privilégios industriais ${ }^{5}$ e loterias para instalação e manutenção das fábricas de papel. O quadro 1, a seguir, ilustra, de forma sucinta, pedidos de empreendedores que foram analisados pela Sociedade Auxiliadora da Indústria Nacional. ${ }^{6}$

Quadro 1 - Resumo de alguns empreendedores que solicitaram loterias e privilégios para instalar fábricas de papel no Brasil entre as décadas de 1840 e 1870.

\begin{tabular}{|c|c|c|c|c|}
\hline Nome & $\begin{array}{c}\text { Local de } \\
\text { instalação }\end{array}$ & Requer & $\begin{array}{c}\text { Matéria- } \\
\text { prima }\end{array}$ & Solicitação [Referência] \\
\hline $\begin{array}{l}\text { José Antônio } \\
\text { de Araújo }\end{array}$ & Salvador/BA & $\begin{array}{l}\text { Lei } n .136 \text {, de } 5 \text { de } \\
\text { março de } 1841.10 \\
\text { loterias. } \\
\text { Lei de } 16 \text { de agosto } \\
\text { de } 1846 \text {. Privilégio de } \\
10 \text { anos para fabricar } \\
\text { papel. }\end{array}$ & $\begin{array}{l}\text { Tronco e } \\
\text { folhas de } \\
\text { bananeira }\end{array}$ & $\begin{array}{l}\text { Sessão da Assembleia } \\
\text { Legislativa Provincial da Bahia, } \\
\text { em } 1841 \text { e } 1846 . \\
\text { [COLLECÇÃO..., 1862, p. 93-94] }\end{array}$ \\
\hline $\begin{array}{l}\text { Augusto } \\
\text { Guilherme } \\
\text { Linde } \\
\text { (Prússia } \\
\text { /Áustria) }\end{array}$ & $\begin{array}{l}\text { Rio de } \\
\text { Janeiro }\end{array}$ & $\begin{array}{l}\text { Privilégio por } 10 \text { anos } \\
\text { para fábrica de papel. }\end{array}$ & $\begin{array}{l}\text { Palha de } \\
\text { milho }\end{array}$ & $\begin{array}{l}\text { Sessão do Conselho de } 16 \text { de } \\
\text { março de } 1863 \text {. } \\
\text { [AIN* }{ }^{*} 1863 \text {, edição } 001 \text {, } \\
\text { p. 135] }\end{array}$ \\
\hline $\begin{array}{l}\text { Guilherme } \\
\text { Schuch de } \\
\text { Capanema } \\
\text { (Brasil) }\end{array}$ & Petrópolis/RJ & $\begin{array}{l}\text { Privilégio por } 10 \text { anos } \\
\text { para fabricar papel } \\
\text { Decreto de } 16 \text { de } \\
\text { dezembro de } 1857 \text {. }\end{array}$ & $\begin{array}{l}\text { Diversas } \\
\text { plantas } \\
\text { nativas como } \\
\text { o gravatá } \\
\text { (fibras } \\
\text { indígenas) }\end{array}$ & $\begin{array}{l}\text { Sessão do Conselho de } 15 \text { de } \\
\text { abril de } 1863 \text {. } \\
\text { [AIN, 1863, edição } 001 \text {, p. 165] }\end{array}$ \\
\hline $\begin{array}{l}\text { Eugênio Muller } \\
\text { (França) }\end{array}$ & Bahia & $\begin{array}{l}\text { Privilégio por } 10 \text { anos } \\
\text { para fabricar papel e } \\
\text { exportar fibras. } \\
\text { Indeferido em } \\
\text { 1/set/1864. } \\
\text { Reapresenta e } \\
\text { expande o pedido. } \\
\text { Fabricação de papel. }\end{array}$ & $\begin{array}{l}\text { Diversas } \\
\text { plantas } \\
\text { nativas } \\
\text { (fibras } \\
\text { indígenas) } \\
\text { Fibra de } \\
\text { bananeira }\end{array}$ & $\begin{array}{l}\text { Sessão do Conselho de } 16 \text { de } \\
\text { agosto de } 1864 . \\
\text { [AIN, ano } 64 \text {, edição } 001, \text { p. } \\
370] \\
\text { Sessão do Conselho de } 2 \text { de } \\
\text { janeiro de } 1865 . \\
\text { [AIN, } 1865 \text {, edição } 001 \text {, p. 49] }\end{array}$ \\
\hline
\end{tabular}

ALMEIDA, Thais Helena de; HANNESCH, Ozana. As primeiras fábricas de papel na cidade do Rio de Janeiro no século XIX.

PÓS:Revista do Programa de Pós-graduação em Artes da EBA/UFMG. v. 11, n. 22, mai-ago. 2021 Disponível em < $\underline{\text { https://doi.org/10.35699/2237-5864.2021.25766 }>}$ 


\begin{tabular}{|c|c|c|c|c|}
\hline $\begin{array}{l}\text { Charles Pradez } \\
\text { e } \\
\text { William F. Jones }\end{array}$ & $\begin{array}{l}\text { Rio de } \\
\text { Janeiro }\end{array}$ & $\begin{array}{l}\text { Privilégio por novo } \\
\text { processo de fazer } \\
\text { papel e isenção de } \\
\text { direitos de alfândega } \\
\text { para matéria-prima } \\
\text { importada e } \\
\text { máquinas } \\
\text { necessárias. }\end{array}$ & Madeira & $\begin{array}{l}\text { Sessão do Conselho de } 1^{\circ} \text { de } \\
\text { setembro de } 1866 . \\
\text { [AIN, 1866, edição julho, p. 367] } \\
\text { Sessão do Conselho de } 8 \text { de } \\
\text { agosto de } 1866 . \\
\text { [AIN, ago/1866, p. } 312-315 \text { ] } \\
\text { Decreto de } 17 \text { de julho de } \\
1867 .\end{array}$ \\
\hline Julius Meyer & Bahia & $\begin{array}{l}\text { Privilégio por } 15 \text { anos } \\
\text { para fabricação de } \\
\text { papel. Concedido em } \\
2 \text { de setembro de } \\
1867 \text {, sobre a } \\
\text { resolução de } \\
\text { concessão por um } \\
\text { ano, até que envie } \\
\text { provas do invento. }\end{array}$ & $\begin{array}{l}\text { Bagaço de } \\
\text { cana-de- } \\
\text { açúcar }\end{array}$ & $\begin{array}{l}\text { Sessão do Conselho de } 10 \text { julho } \\
\text { de } 1867 . \\
\text { [AIN, ago/1867, p. 322] } \\
\text { Sessão do Conselho de } 2 \text { de } \\
\text { setembro de } 1867 . \\
\text { [AIN, out/1867, p. 388-390; AIN, } \\
\text { nov/1867, p. 451] }\end{array}$ \\
\hline $\begin{array}{l}\text { Henrique } \\
\text { Bochet } \\
\text { (França) }\end{array}$ & $\begin{array}{l}\text { Não } \\
\text { mencionado. }\end{array}$ & $\begin{array}{l}\text { Ser considerado } \\
\text { introdutor da } \\
\text { fabricação com } \\
\text { bagaço de cana-de- } \\
\text { açúcar. }\end{array}$ & - & $\begin{array}{l}\text { Sessão do Conselho de } 17 \text { de } \\
\text { outubro de } 1867 . \\
\text { [AIN, } 1867 \text {, edição } 001, \text { p. } 431 \text { - } \\
432 \text { ] } \\
\text { Sessão de } 13 \text { de novembro de } \\
1867 . \\
\text { [AIN, dez/1867, p. } 544]\end{array}$ \\
\hline $\begin{array}{l}\text { Emmanuel } \\
\text { Frank } \\
\text { (Alemanha) }\end{array}$ & $\begin{array}{l}\text { Santa } \\
\text { Catarina }\end{array}$ & $\begin{array}{l}\text { Privilégio de } 10 \text { anos } \\
\text { para fábrica de papel. } \\
\text { Concedido por } \\
\text { Decreto em } 22 \text { de } \\
\text { fevereiro de } 1872 \text {. }\end{array}$ & $\begin{array}{l}\text { Esparto, } \\
\text { bambu, } \\
\text { palha de } \\
\text { milho e } \\
\text { outras } \\
\text { folhagens }\end{array}$ & $\begin{array}{l}\text { Sessão da Sociedade } \\
\text { Auxiliadora de } 1^{\circ} \text { de junho de } \\
1871 . \\
\text { [AIN, out/1878, p. 223] }\end{array}$ \\
\hline $\begin{array}{l}\text { Henrique } \\
\text { Mamede Lins } \\
\text { de Almeida }\end{array}$ & $\begin{array}{l}\text { Pernambuco } \\
\text { (?) }\end{array}$ & $\begin{array}{l}\text { Privilégio para } \\
\text { fabricação de papel. }\end{array}$ & - & $\begin{array}{l}\text { Sessão da Sociedade } \\
\text { Auxiliadora de } 1^{\circ} \text { de setembro } \\
\text { de } 1871 . \\
\text { [AIN, out/1878, p. } 223 \text { ] }\end{array}$ \\
\hline
\end{tabular}

ALMEIDA, Thais Helena de; HANNESCH, Ozana. As primeiras fábricas de papel na cidade do Rio de Janeiro no século XIX.

PÓS:Revista do Programa de Pós-graduação em Artes da EBA/UFMG. v. 11, n. 22, mai-ago. 2021 Disponível em $<\underline{\text { https://doi.org/10.35699/2237-5864.2021.25766 }>}$ 


\begin{tabular}{|c|c|c|c|c|}
\hline $\begin{array}{l}\text { Vincent Elyah } \\
\text { Heegan } \\
\text { (Estados } \\
\text { Unidos) }\end{array}$ & $\begin{array}{l}\text { Não } \\
\text { mencionado. }\end{array}$ & $\begin{array}{l}\text { Privilégio de } 20 \text { anos } \\
\text { para preparação de } \\
\text { polpa extraída da } \\
\text { madeira para fabrico } \\
\text { de papel. }\end{array}$ & $\begin{array}{l}\text { Polpa } \\
\text { extraída da } \\
\text { madeira }\end{array}$ & $\begin{array}{l}\text { Sessão da Sociedade } \\
\text { Auxiliadora de } 10 \text { de março de } \\
1872 . \\
\text { [AIN, out/1878, p. } 223 \text { ] } \\
\text { Decreto n० } 5028 \text { de } 24 \text { de julho } \\
\text { de } 1872\end{array}$ \\
\hline John Ring & $\begin{array}{l}\text { Rio Grande } \\
\text { do Sul }\end{array}$ & Fabricação de papel. & $\begin{array}{l}\text { Vegetais do } \\
\text { Brasil }\end{array}$ & $\begin{array}{l}\text { Sessão da Sociedade } \\
\text { Auxiliadora de } 4 \text { de novembro } \\
\text { de } 1873 . \\
\text { [AIN, out/1878, p. } 223 \text { ] }\end{array}$ \\
\hline $\begin{array}{l}\text { Samuel } \\
\text { Severiano } \\
\text { Figueira de } \\
\text { Aguiare } \\
\text { Francisco } \\
\text { Carlos da Silva }\end{array}$ & São Paulo & $\begin{array}{l}\text { Privilégio de } 20 \text { anos } \\
\text { para estabelecer } \\
\text { fábrica de papel. }\end{array}$ & - & $\begin{array}{l}\text { Sessão da Sociedade } \\
\text { Auxiliadora de } 12 \text { de agosto de } \\
1878 . \\
\text { [AIN, out/1878, p. 223] }\end{array}$ \\
\hline
\end{tabular}

Fonte: O Auxiliador da Indústria Nacional, 1863-1878. (Hemeroteca Digital/FBN). Quadro elaborado pelas autoras.

Como é possível observar, o Alvará de 24 de abril de 1809 impulsionou a implantação de fábricas no Brasil, e as de papel não foram exceção. Parte desse interesse, já na época do Império, veio da busca de se identificar fibras da flora nativa, sob as quais a possibilidade de explorar gerava condições de exclusividade de longo prazo.

\section{Extração de fibras e os Privilégios Industriais do Império}

O tema dos privilégios industriais e do direito à propriedade industrial se iniciou no Brasil com a publicação do Alvará de 1809, cujo texto decretava que inventores e autores teriam direito de exclusividade por 14 anos, e registrariam seu invento na Real Junta do Comércio (ALVARÁ..., 1809). Apenas em 30 de agosto de 1830, Dom Pedro I instituiu uma lei ${ }^{7}$ promovendo e disciplinando a concessão de privilégios, sobre os quais se outorgaria uma patente, com duração de 5 a 20 anos segundo a qualidade de descoberta ou invenção, ou um prêmio, conforme sua utilidade ou dificuldade de introdução (LEl..., 1830). Mas o tema dos privilégios aparece repetidas vezes em jornais e revistas do Rio de Janeiro entre as décadas de 1850 e 1860. Esta situação ocorre quando o Conselho Administrativo da Sociedade Auxiliadora da Indústria Nacional ${ }^{8}$ estava discutindo a

ALMEIDA, Thais Helena de; HANNESCH, Ozana. As primeiras fábricas de papel na cidade do Rio de Janeiro no século XIX.

PÓS:Revista do Programa de Pós-graduação em Artes da EBA/UFMG. v. 11, n. 22, mai-ago. 2021 Disponível em < $\underline{\text { https://doi.org/10.35699/2237-5864.2021.25766 }}>$ 
necessidade de criação de normas para se evitar o número exagerado de concessão das autorizações e de regular o tempo concedido e suas finalidades. A opinião do Conselho é que os privilégios, em geral, tendiam mais a paralisar a indústria nos países novos, do que desenvolvê-la (SESSÃO..., 1867, p. 315).

Identificou-se que, na segunda metade do século XIX, várias tentativas e pretensões análogas foram abortadas ou não tiveram êxito pela pouca garantia frente à concorrência com produtos similares estrangeiros. No caso da indústria papeleira, a falta da matéria era fato, mas havia diferentes esforços em substituí-la por outras fibras de origem vegetal nativas de diferentes espécies. $O$ Brasil teria condições de abastecer esse mercado, pois dispunha de inúmeros vegetais, cujas propriedades eram reconhecidamente aplicáveis para fabricação do papel. Um exemplo dessa afirmação é o artigo "Das materias vegetaes, indigenas e exóticas, próprias para fabricar tecidos e papel, cordas cabos e outros usos", publicado pela revista O Auxiliador da Indústria Nacional (DAS MATERIAS..., 1864, p. 459-468).

Por outro lado, se verificou também que muitas solicitações de privilégio não se enquadravam na forma da lei de 30 de agosto de 1830. Talvez por esse motivo, a Sociedade Auxiliadora da Indústria Nacional tenha sugerido ao então governo imperial que concedesse prêmios, favores ou garantias que facilitassem o estabelecimento da indústria que se pretendia prosperar (FREITAS; LIMA, 1878).

\section{Conclusão}

No século XIX, o apoio do império, com a concessão de loterias e privilégios industriais, para o desenvolvimento das fábricas na cidade do Rio de Janeiro, impulsionou diversos empreendimentos e fábricas de papel. Entretanto, a indústria papeleira encontrou desafios, como a falta de mão de obra especializada, escassez de matéria-prima e importação de insumos e maquinário. A fábrica de Joaquim José da Silva se destacou no início do século XIX, mas sua produção parece ter se limitado ao uso de trapos nacionais e importados. Somente nas décadas de 1830 e 1840, André Gaillard e Zeferino Ferrez implementaram, por meio de seus esforços para produzir papel e encontrar fibras vegetais nativas, uma iniciativa fabril papeleira, que fomentou outros empreendedores a pesquisar novas possibilidades e desenvolver essa indústria nacional. Os incentivos do governo mencionados neste artigo, como as loterias e o privilégio industrial, possibilitaram investimento por parte dos

ALMEIDA, Thais Helena de; HANNESCH, Ozana. As primeiras fábricas de papel na cidade do Rio de Janeiro no século XIX.

PÓS:Revista do Programa de Pós-graduação em Artes da EBA/UFMG. v. 11, n. 22, mai-ago. 2021 Disponível em < $\underline{\text { https://doi.org/10.35699/2237-5864.2021.25766 }}>$ 
fabricantes de papel na modernização do processo industrial, na pesquisa por matéria-prima nacional e na ampliação do comércio e negócios. Contudo, os problemas econômicos, técnicos e de ordem pessoal foram decisivos para a manutenção ou falência de algumas dessas fábricas.

Como é possível observar, muitas delas não prosperaram e, ao final do século XIX, segundo as informações até o momento obtidas, a maioria estava em situação deplorável. Porém, a pesquisa mostrou que a introdução deste gênero de produto, no Brasil, foi concorrente com a busca de matérias-primas alternativas para a produção de papel, e que o governo contribuiu com incentivos. No período analisado, identificam-se muitos empreendedores, desbravadores locais com pouca infraestrutura, mas com boa condição de fornecimento de água, requisito fundamental para uma instalação papeleira. O destino dessas fábricas, contudo, ainda deixa muitas questões para pesquisa sobre o tema..

ALMEIDA, Thais Helena de; HANNESCH, Ozana. As primeiras fábricas de papel na cidade do Rio de Janeiro no século XIX.

PÓS:Revista do Programa de Pós-graduação em Artes da EBA/UFMG. v. 11, n. 22, mai-ago. 2021 Disponível em < $\underline{\text { https://doi.org/10.35699/2237-5864.2021.25766 }}>$ 


\section{REFERÊNCIAS}

ALCANTARA, J. J. de. Planta da cidade de S. Sebastião do Rio de Janeiro e da maior parte de seus termos: começada a levantar em 1826 e interrompida desde 1828 pelos officiais empregados no Archivo Militar da Corte. Rio de Janeiro: Archivo Militar da Corte, 1842. 1 mapa. Escala em 1.000 braças: desenho em nanquim, aquarelado.

ALVARÁ do império no de 01 de abril de 1808. Permitte o livre estabelecimento de fabricas e manufacturas no Estado do Brazil. Disponível em:

<https://www.planalto.gov.br/ccivil_03/atos/alv/1808/alv-1-4-1808.html>. Acesso em: 25 set. 2020.

ALVARÁ de 28 de abril de 1809. Isenta de direitos ás materias primaz do uso das fabricas e concede outros favores aos fabricantes e da navegação Nacional. Disponível em:

$<$ https://www2.camara.leg.br/legin/fed/alvara/anterioresa1824/alvara-40051-28-abril-1809-

571629-publicacaooriginal-94774-pe.html>. Acesso em: 25 set. 2020.

ALVARÁ que proibe as fábricas e manufaturas no Brasil. Arquivo Nacional e a História Luso-

Brasileira, 21 jun. 2018. Disponível em: <http://historiacolonial.arquivonacional.gov.br/index.php? option=com_content\&view=article\&id=3674\&catid=145\&ltemid=286>. Acesso em 25 set. 2020.

ANNUNCIOS. Diario do Rio de Janeiro, Rio de Janeiro, n. 39, p. 3, 8 fev. 1854.

AO PUBLICO. Jornal do Commercio, Rio de Janeiro, n. 283, p. 1-2, 17 out. 1845a. Suplemento.

AO PUBLICO. Jornal do Commercio, Rio de Janeiro, n. 287, p. 1, 21 out. 1845b.

ARQUIVO NACIONAL (Brasil). Coordenação de Documentos Escritos. Equipe de Documentos do Executivo e Legislativo. Coleção Privilégios Industriais (PI): inventário analítico - conteúdo por notação. 2. ed. rev. Rio de Janeiro: Arquivo Nacional, 2013. p. 8.

ASSEMBLÉA Geral Legislativa (sessão de 1847), sessão imperial da abertura da Assembléa Geral Legislativa, no dia 3 de maio de 1847. Annuario Político Histórico e Estatístico do Brazil, Rio de Janeiro, ano 2, p. 32, 1847.

ASSEMBLEIA Geral Legislativa. Senado. Diario do Rio de Janeiro, Rio de Janeiro, anno 38, n. 127, p. 2, 12 maio 1858.

AVISOS. Gazeta do Rio de Janeiro, Rio de Janeiro, p. 4, 1 fev. 1817.

AVISOS. Gazeta do Rio de Janeiro, Rio de Janeiro, p. 4, 4 abr. 1818.

BRASIL. Decreto no 357, 27 de abril de 1844. Regulamenta a extração das Loterias. [S.I.]: Senado Federal, 1844.

CÂMARA dos Senhores Senadores: acta de 17 junho de 1839. Presidência do Sr. Diogo Antonio Feijó. O Despertador, Rio de Janeiro, p. 1, 18 jun. 1839.

CAMARA Municipal, $11^{\text {a }}$. sessão em 6 de março de 1849. Diario do Rio de Janeiro, Rio de Janeiro, anno 28, n. 8073 , p. 5,18 abr. 1849 . Suplemento.

ALMEIDA, Thais Helena de; HANNESCH, Ozana. As primeiras fábricas de papel na cidade do Rio de Janeiro no século XIX.

PÓS:Revista do Programa de Pós-graduação em Artes da EBA/UFMG. v. 11, n. 22, mai-ago. 2021 Disponível em < $\underline{\text { https://doi.org/10.35699/2237-5864.2021.25766 }>}$ 
CAVALCANTI, João Cruvelo. Nova numeração dos prédios da cidade do Rio de Janeiro. Rio de Janeiro: Oficinas Gráficas do Depto de Impressa Oficial da Secret. Municipal de Administração, 1878. 2 v. (Coleção Memória do Rio 6, I-II)

CAVALCANTI, Nireu Oliveira. O Rio de Janeiro setecentista: a vida e a construção da cidade da invasão francesa até a chegada da Corte. Rio de Janeiro: Zahar, 2004.

CENTRO dos Fabricantes Nacionais de Papel. A marca d'água no papel da imprensa e a indústria nacional de papel. São Paulo: Melhoramentos, [1926?]. Disponível em:

$<$ https://archive.org/details/marcadagua00papel/page/40/mode/2up >. Acesso em: 25 de setembro, 2020.

COLLECÇÃO das Leis e Resoluções da Assemblea Legislativa da Bahia, sancionadas e publicadas nos anos de 1840 e 1841. v. III, contendo 118 e 152. Bahia: Typographia de Antonio Ollavo da França Guerra, 1862.

CORRESPONDENCIA. O Moderador, novo correio do Brasil, jornal político, commercial e litterario, Rio de Janeiro, p. 4, 5 maio 1830.

DAS MATERIAS vegetaes, indigenas e exóticas, próprias para fabricar tecidos e papel, cordas cabos e outros usos. O Auxiliador da Indústria Nacional, Rio de Janeiro, n. 12, p. 459-468, dez. 1864.

FALLECIMENTO. Diário do Rio de Janeiro, Rio de Janeiro, anno 24, n. 14, p. 1, 14 jan. 1855.

FAVOR á indústria. O Chronista, Rio de Janeiro, n. 229, p. 916, 13 set. 1838. Disponível em: <http://memoria.bn.br/pdf/702811/per702811_1838_00229.pdf>. Acesso em 25 set. 2020.

FERREZ, Gilberto. Os irmãos Ferrez da missão artística francesa. Revista do Instituto Histórico e Geográfico Brasileiro, Rio de Janeiro, v. 275, p. 3-54, abr.-jun. 1967.

FREITAS, Dr. Antonio de Paula; LIMA, João Franklin de Alencar. Sala das sessões da Sociedade Auxiliadora da Industria Nacional, em 12 de agosto de 1878. O Auxiliador da Indústria Nacional, Rio de Janeiro, n.10, p. 4, out. 1878.

LEl de 28 de agosto de 1830: concede privilégio ao que descobrir, inventar ou melhorar uma industria útil e um premio que introduzir uma industria estrangeira e regula sua concessão. Disponível em: <http://www.planalto.gov.br/ccivil_03/leis/LIM/LIM-28-8-1830.htm>. Acesso em: 25 set. 2020.

LORENA, Bernardo José de. [correspondência]. Destinatário: para o Conde de Linhares: Vila Rica, 20 nov. 1799. 1 carta. Arquivo Histórico Ultramarino. Anexo: carta ( $2^{\mathrm{a}}$ via). $\mathrm{N}^{\circ}$ de inventário no catálogo: 11099 AHU-Minas Gerais, cx.151, doc. 16 - AHU_CU_011, cx. 154, D.11357.

LORENA, Bernardo José de. [correspondência]. Destinatário: para o Conde de Linhares: Vila Rica, 15 nov. 1800. 1 carta. Arquivo Histórico Ultramarino. Anexo: relação. № de inventário no catálogo: 11382 AHU-Minas Gerais, cx.154, doc.44. AHU_CU_011,cx. 154, D.11593

LORENA, Bernardo José de. [correspondência]. Destinatário: para o Conde de Linhares: Vila Rica, 30 jan. 1801. 1 carta. Arquivo Histórico Ultramarino. Anexo: relações, carta (2a via). № de inventário no catálogo: 11676 AHU-Minas Gerais, cx, 156, doc. 22 - AHU_CU_011, Cx. 156, D.11713.

ALMEIDA, Thais Helena de; HANNESCH, Ozana. As primeiras fábricas de papel na cidade do Rio de Janeiro no século XIX.

PÓS:Revista do Programa de Pós-graduação em Artes da EBA/UFMG. v. 11, n. 22, mai-ago. 2021 Disponível em < $\underline{\text { https://doi.org/10.35699/2237-5864.2021.25766 }}>$ 
MINISTERIO da Agric., Comm. E Obra. Publ. Boletim do Expediente do Governo [do] Ministério do Império, Rio de Janeiro, n. 30, p. 24-25, 28 jan. 1862a.

MINISTERIO da Fazenda. Boletim do Expediente do Governo, Rio de Janeiro, t. 37, p. 9-10, 19 ago. 1862b.

MINISTERIO da Fazenda, expediente do dia 7 de fevereiro de 1839. Correio Official, Rio de Janeiro, v. 1, n. 86, p. 142,13 fev. 1839.

MINISTERIO da Fazenda, Correio Official, Rio de Janeiro, v.1, n. 59, p. 234, 12 mar. 1840.

MINISTERIO do Império, Correio Official: in medio posita virtus, Rio de Janeiro, t.1, n. 99, p. 4, 24 out. 1833.

NOT. particulares. Diário do Rio de Janeiro, Rio de Janeiro, anno 24, n. 6912, p. 4, 14 maio 1845.

NOTICIAS particulares. Diário do Rio de Janeiro, Rio de Janeiro, anno 18, n. 192, p. 4, 29 ago. 1839.

O DIARIO: 1 de janeiro. Diário do Rio de Janeiro, Rio de Janeiro, anno 28, n. 7982, p. 3, 2 jan. 1849.

O PARLAMENTAR impresso em papel nacional. O Parlamentar, Rio de Janeiro, p. 93, 12 set. 1838.

PLANTA da Cidade do Rio de Janeiro. Trab. do Engenheiro A. Santana, s. I., 5 de abril de 1870.

Arquivo Nacional. Fundo do Minist. da Agricultura, Comércio e Obras Públicas. Documento dividido em partes [pranchas coloridas], f. 87. Código de referência: BR-RJANRIO-4M-0-MAP-0118-f-87

PLANTA da muito leal e heroica cidade de São Sebastião do Rio de Janeiro. Desenhada por Jonh Edgar Ker. Paris: Garnier, 1852. 1 planta; 73 x 105 cm, escala 1:8.400.

PUBLICAÇOES do Foro. Arrematações judiciarias. Correio Mercantil, Rio de Janeiro, anno 14, n. 82, p. 2, 4 out. 1857.

RELATORIO da Repartição dos Negócios do Império. Rio de Janeiro: Typographia Nacional, 1847. p. 27-28

RELATORIO da Repartição dos Negócios do Império, apresentado à Assembleia Geral Legislativa, na $1^{\text {a }}$ sessão da 7a legislatura. Rio de Janeiro:Typographia Nacional, 1848. p. 28

RELATORIO da Repartição dos Negócios do Império, apresentado à Assembleia Geral Legislativa, na $1^{\text {a }}$ sessão da 10a legislatura. Rio de Janeiro: Typographia imperial constitucional de J. Villeneuve, 1857. p. 116

REPRESENTAÇÃO de Manoel Machado de Coelho e outros, proprietários das fábricas de estamparia e papel a S.M.l., solicitando isenção de impostos para compra de fazendas e tintas estrangeiras e incentivo da utilização de mão de obra para o desenvolvimento da indústria no país. [Rio de Janeiro], [1823], 7 p. Documento 41.

Biblioteca Nacional. Divisão de Manuscritos: mss1427854 II-34,27,026. Disponível em: $<$ http://objdigital.bn.br/objdigital2/acervo_digital/div_manuscritos/mss1427854/ mss1427854.pdf>. Acesso em: 25 de setembro, 2020.

RIO de Janeiro. Assembléia Geral Legislativa. Senado, sessão em 26 de setembro. Jornal do Commercio, Rio de Janeiro, anno 13, n.215, p. 1, 27 set. 1838a.

ALMEIDA, Thais Helena de; HANNESCH, Ozana. As primeiras fábricas de papel na cidade do Rio de Janeiro no século XIX.

PÓS:Revista do Programa de Pós-graduação em Artes da EBA/UFMG. v. 11, n. 22, mai-ago. 2021 Disponível em < $\underline{\text { https://doi.org/10.35699/2237-5864.2021.25766 }>}$ 
RIO de Janeiro: Câmara dos Deputados, sessão de 3 de setembro. Diário do Rio de Janeiro, Rio de Janeiro, anno 17, n. 198, p. 1, 4 set. 1838b.

RIO de Janeiro: Câmara dos Deputados, sessão em 14 de setembro. Diario do Rio de Janeiro, Rio de Janeiro, anno 17, n. 206, p. 1, 15 set. 1838 c.

RIO de Janeiro: Câmara dos Deputados, sessão em 10 de junho. Diário do Rio de Janeiro, Rio de Janeiro, anno 25, n. 7226, p. 1, 6 jun. 1846a.

RIO de Janeiro: Câmara dos Deputados, sessão em 11 de fevereiro de 1850. Diário do Rio de Janeiro, Rio de Janeiro, anno 29, n. 8326, p. 2, 13 fev. 1850a.

RIO de Janeiro: Câmara dos Deputados, sessão em 10 de abril de 1850. Diario do Rio de Janeiro, Rio de Janeiro, anno 29, n. 8371, p. 2, 11 abr. 1850b.

RIO de Janeiro. Câmara dos Srs Senadores, sessão de 18 de maio de 1847. Diario do Rio de Janeiro, Rio de Janeiro, anno 26, n. 7505, p. 2, 20 maio 1847.

RIO de Janeiro. Senado. Jornal do Commercio, Rio de Janeiro, anno 21, n. 219, p. 1, 9 ago. 1846b.

SENADO. Diario do Rio de Janeiro, Rio de Janeiro, anno 52, n. 275, p. 5, 8 out. 1869. Suplemento.

SESSÃO do Conselho Administrativo em 1 de junho de 1867. Auxiliador da Indústria Nacional, Rio de Janeiro, n.8, p. 315, ago. 1867.

SOCIEDADE Auxiliadora da Industria Nacional. O Auxiliador da Indústria Nacional, Rio de Janeiro, v. 4 da nova série, p. 41-57, 1855.

SOCIEDADE Auxiliadora da Industria Nacional. O Auxiliador da Indústria Nacional, v. 55, n. 7, p. 144-168, jul. 1887.

URBINATI, Inoã Carvalho; LAMARÃO, Sergio. Sociedade Auxiliadora da Indústria Nacional (SAIN). In: ABREU, Alzira Alves de (org.). Dicionário histórico-biográfico da Primeira República (18891930). Rio de Janeiro: FGV: CPDOC, 2015. Disponível em:

$<$ http://cpdoc.fgv.br/sites/default/files/verbetes/primeira-republica/SOCIEDADE\%20AUXILIADORA \%20DA\%20IND\%C3\%9ASTRIA\%20NACIONAL.pdf>. Acesso em: 20 set. 2020.

VARIEDADES. Pharol do Império, Rio de Janeiro, anno 1, n. 10, p. 3, 30 mar. 1837.

VELOSO, José Mariano da Conceição. Carta do frei José Mariano Veloso ao conde de Linhares enviando amostra do primeiro papel fabricado no Rio de Janeiro, com embira do Brasil. 22/11/1809. Museu Imperial, Coleção do Arquivo da Casa Imperial do Brasil. Documento manuscrito. MFN: 00352

VENDAS. Diário do Rio de Janeiro, Rio de Janeiro, anno 33, n. 6544, p. 3, 10 fev. 1844.

ALMEIDA, Thais Helena de; HANNESCH, Ozana. As primeiras fábricas de papel na cidade do Rio de Janeiro no século XIX.

PÓS:Revista do Programa de Pós-graduação em Artes da EBA/UFMG. v. 11, n. 22, mai-ago. 2021 Disponível em < $\underline{\text { https://doi.org/10.35699/2237-5864.2021.25766 }>}$ 


\section{NOTAS}

1 Andaraí Pequeno é o atual bairro da Tijuca.

2 Esta rua começava no fim da rua Conde Bonfim e terminava na estrada velha da Tijuca (CAVALCANTI, 1878, p. 882).

3 Atual região dos bairros Andaraí e parte de Vila Isabel.

4 Naquela época o termo se referia ao papel de parede.

5 Esses eram concessões dadas pelo Império para produção exclusiva de algum bem ou processo, em razão de comprovação de invenção ou inovação. A técnica, material ou objeto recebia um registro, o qual ficava depositado e garantia que somente o proprietário podia usufruir daquele privilégio de produção por um número de anos estabelecido em lei. Atualmente é similar ao que chamamos de marca e patente.

6 Uma explicação sobre a entidade é apresentada no item "Extração de fibras e os Privilégios Industriais do Império", a seguir.

7 Esse direito era passado por decreto público e ao inventor se concedia uma carta patente, assinada pelo governante e referendada pelo Ministro do Império (até 1860). Uma duplicata/amostra, relatório descritivo com desenhos e modelos deviam ser entregues (ARQUIVO, 2013).

8 Foi uma entidade fundada em outubro de 1827, com o propósito de "promover por todos os meios ao seu alcance, o melhoramento e a prosperidade da indústria no Império do Brasil". Atuou como órgão consultivo do governo imperial, examinando e emitindo pareceres, que eram encaminhados ao Ministro do Império e, posteriormente, ao Ministério dos Negócios da Agricultura, Comércio e Obras Públicas, até 1889, quando foi proclamada a República. Continua atuante até a primeira década do século XX (URBINATI; LARMARÃO, 2015). 